\title{
Managementul tulburărilor respiratorii obstructive în somn la copilul 2-18 ani din perspectiva Societății Europene de Pneumologie (ERS)
}

\author{
Sorina Chindris ${ }^{1,2}$, Doina-Anca Pleşca ${ }^{1,2}$ \\ ${ }^{1}$ Facultatea de Medicină, UMF "Carol Davila“, Bucureşti, România \\ ${ }^{2}$ Spitalul Clinic de Copii „Dr. Victor Gomoiu“, Bucureşti, România
}

\begin{abstract}
REZUMAT
Tulburările respiratorii obstructive din timpul somnului la copil şi adolescent reprezintă o patologie de actualitate atât prin prisma mecanismelor de evaluare diagnostică, cât şi prin cea a măsurilor terapeutice aflate în continuă abordare multidisciplinară.

Experţii din cadrul Societăţii Europene de Pneumologie au încercat să prezinte un guideline în evaluarea şi manage-mentul copilului cu tulburări respiratorii obstructive apărute în timpul somnului (SASO). În acest articol vom aborda populaţia pediatrică cuprinsă între 2 şi 18 ani.

SASO este definit prin prezenţa semnelor şi a simptomelor specifice obstrucţiei parţiale sau complete a căilor respiratorii superioare, evenimente care apar în timpul somnului.

Evaluarea obiectivă a SASO se face, de elecţie, prin folosirea polisomnografiei ca metodă de diagnostic. Astfel, un indice apnee:hipopnee $>5$ evenimente/oră sau un indice apnee:hipopnee $>1$ eveniment/oră, dar, în prezenţa facto-rilor de risc sau a comorbidităţilor asociate, se impune instituirea metodelor de tratament specifice. Adenoidectomia rămâne prima linie de tratament a SASO la copiii cu hipertrofie adenoidoamigdaliană. Măsurile intervenţionale sunt extrem de variate. Astfel, pot să fie utilizate dispozitive orale, se poate institui terapie cu ventilaţie noninvazivă, terapie medicamentoasă sau intervenţie chirurgicală etc. Fiecare măsură intervenţională va fi individualizată cu scopul de a îmbunătăţi calitatea vieţii fiecărui pacient în parte. Rolul lor este de a obţine ameliorare/vindecare clinică şi de a înlătura eventualele complicaţii care pot apărea în timp.

Toate aceste aspecte complexe aduc împreună medici din specialităţi diferite, pentru a oferi pacienţilor cele mai eficiente îngrijiri şi servicii medicale.
\end{abstract}

Cuvinte cheie: tulburări respiratorii în somn, apnee în somn, polisomnografie, ventilaţie noninvazivă, copil

\section{INTRODUCERE. TERMINOLOGIE. DATE EPIDEMIOLOGICE}

Somnul, alături de activităţile din perioada de veghe, reprezintă un element deosebit de important în organizarea şi funcţionarea corpului uman.

În timpul somnului, se desfăşoară procese esenţiale pentru dezvoltarea armonioasă, psihomotorie şi neurocomportamentală a copilului, precum şi pentru secreţia hormonilor de creştere, reglarea temperaturii corporale, memoria şi învăţarea, creativitatea şi modelarea funcţiilor emoţionale, îmbunătăţirea activităţii imune, dezvoltarea cerebrală etc. (1). Somnul este definit ca o activitate naturală, dinamică, fiziologică, care se succede periodic, în care organismul se odihneşte şi starea de conştienţă este suspendată (2).
Tulburările respiratorii obstructive din timpul somnului la copil (SASO) apar secundar disfuncţiei căilor respiratorii superioare, pe perioada somnului.

Tulburările respiratorii în somn la copil reprezintă un spectru clinic larg de condiţii fiziopatologice caracterizate prin obstrucţia parţială sau completă a căilor respiratorii superioare, evenimente care apar pe perioada somnului.

În literatură, se descriu mai multe forme clinice de tulburări respiratorii care apar în somn. Astfel, pot fi întâlnite: sforăitul primar, sindromul de rezistenţă în căile respiratorii superioare, apneea obstructivă de somn cu diferite forme de gravitate.

Sforăitul primar se defineşte prin prezenţa sforăitului frecvent, mai mult de 3 ori pe săptămână, care nu trezeşte copilul din somn. Sforăitul primar nu asocia- 
ză o patologie evidentă a căilor respiratorii superioare şi nu are consecinţe majore respiratorii (apnee, hipoventilaţie, hipercapnie sau tulburări de somn) (3).

Sindromul de rezistenţă în căile respiratorii superioare este o tulburare respiratorie apărută în timpul somnului, care asociază efort inspirator crescut, ronhopatii şi posibil tablou clinic (fragmentarea somnului, somnolenţă diurnă, fatigabilitate, agitaţie). Asociază microtreziri, poate fi însoţit de scăderi ale saturaţiei în oxigen în aerul atmosferic până la 3\%, dar nu se înregistrează evenimente obstructive (3).

Apneea obstructivă de somn este o condiţie patologică asociată cu episoade repetate de obstrucţie parţială sau completă a căilor respiratorii superioare care survin în timpul somnului, au o durată de minimum $10 \mathrm{sec} / 2$ cicluri respiratorii. Această formă clinică asociază efort inspirator în timpul somnului şi determină tulburări de ventilaţie (3).

Cel mai frecvent simptom întâlnit în cadrul tulburărilor respiratorii în somn la copil este sforăitul. Acesta apare cu o prevalenţă de aproximativ $7,45 \%$ în rândul copiilor (4). Prevalenta SASO în rândul populaţiei pediatrice este cuprinsă între 0,1 şi $13 \%$. Acesta se întâlneşte la toate grupele de vârstă, de la nou-născut la adolescent, fiind mult mai frecvent la preşcolar (4).

\section{FIZIOPATOLOGIE}

Sunt descrise cel puţin 4 mecanisme patofiziologice care stau la baza manifestărilor din cadrul tulburărilor respiratorii asociate somnului la copil $(1,5)$ :

Hipertrofia amigdalelor şi a vegetaţiilor adenoide - este considerată cea mai frecventă cauza a SASO la copil. Creşterea în volum a amigdalelor/vegetaţiilor adenoidiene poate produce colapsul căilor respiratorii superioare în timpul somnului, cu grade variate de restricţie a fluxului de aer.

Anatomia craniofacială - dismorfismul craniofacial sau malformaţiile craniofaciale reprezintă o altă cauză frecventă a SASO la copil. Modificările de ventilaţie sunt direct proporţionale cu înaintarea în vârstă şi cu modificările structurii osoase faciocraniene.

Afectarea muşchilor respiratori care apare în cadrul a numeroase boli neuromusculare, boli genetice şi de metabolism. Absenţa sau scăderea progresivă a suportului muscular respirator este secundară atrofiei musculare progresive şi scăderii în dinamică a amplitudinii distensiei cutiei toracice. Toate aceste modificări determină grade diferite de obstrucţie la nivelul căilor respiratorii superioare şi, secundar, fenomene de hipoxie, hipoventilaţie, hipercapnie.

Obezitatea reprezintă o cauză importantă a SASO în populaţia pediatrică prin implicaţiile clinice şi consecinţele metabolice pe care aceasta le are asupra întregului organism.

\section{MANIFESTĂRI CLINICE}

Simptomatologia determinată de SASO este complexă. Se poate exprima clinic printr-o paletă variată de semne şi simptome care apar atât în timpul somnului, cât şi în starea de veghe: somn neliniştit sau fragmentat, sforăit, enurezis, coşmaruri, cefalee matinală, somnolenţă diurnă, agresivitate, dificultăţi de concentrare sau de învăţare, tulburări de vorbire, simptomatologie din spectrul deficitului de atenţie, tulburări de creştere, semne şi simptome cardiovasculare (HTA, tulburări de ritm cardiac etc.) (6).

\section{DIAGNOSTIC ŞI MANAGEMENT}

În prezent, există mai multe tehnici de screening şi diagnostic al tulburărilor respiratorii obstructive în timpul somnului: pulsoximetria nocturnă, poligrafia cardiorespiratorie, polisomnografia, înregistrările video, actigrafia etc.

Polisomnografia (PSG) este considerată metoda "gold-standard" de diagnostic a SASO. Polisomnografia este o investigaţie laborioasă, complexă şi, totodată, consumatoare de timp, de resurse fizice şi financiare. Investigaţia oferă, la acest moment, cele mai multe informaţii despre arhitectura somnului, despre evenimentele neurologice şi cardiorespiratorii asociate somnului.

Traseul polisomnografic include monitorizarea parametrilor neurologici şi cardiorespiratori. Evaluarea parametrilor neurologici şi a structurii somnului se face prin elecroencefalogramă, electrooculogramă, elecromiogramă, mişcările picioarelor etc. Parametrii cardiorespiratori însumează informaţii de la senzorii de flux oronazal, mişcările toracice şi abdominale, pulsoximetrie, activitatea cardiacă, monitorizarea nocturnă a valorilor dioxidului de carbon etc.

Experţii din cadrul Comitetului Ştiinţific al Societăţii Europene de Pneumologie au elaborat un protocol de diagnostic şi management al tulburărilor respiratorii obstructive din timpul somnului la copil. Acesta conţine mai mulţi paşi care validează traseul de evaluare a pacientului pediatric cu vârsta cuprinsă între 2 şi 18 ani, cu patologie respiratorie în timpul somnului. Algoritmul ţine cont de întreg tabloul anamnestico-clinic al pacientului şi de comorbidităţile asociate, în vederea asigurării celor mai corecte strategii de management pentru fiecare copil, în funcţie de patologia acestuia (7).

Tabelul 1 prezintă principalii parametri care ridică suspiciunea unei posibile tulburări respiratorii obstructive în timpul somnului la copil. Aceşti parametri sunt corelaţi cu factorii de risc şi cu comorbidităţile asociate ale fiecărui pacient în parte, precum şi cu fac- 


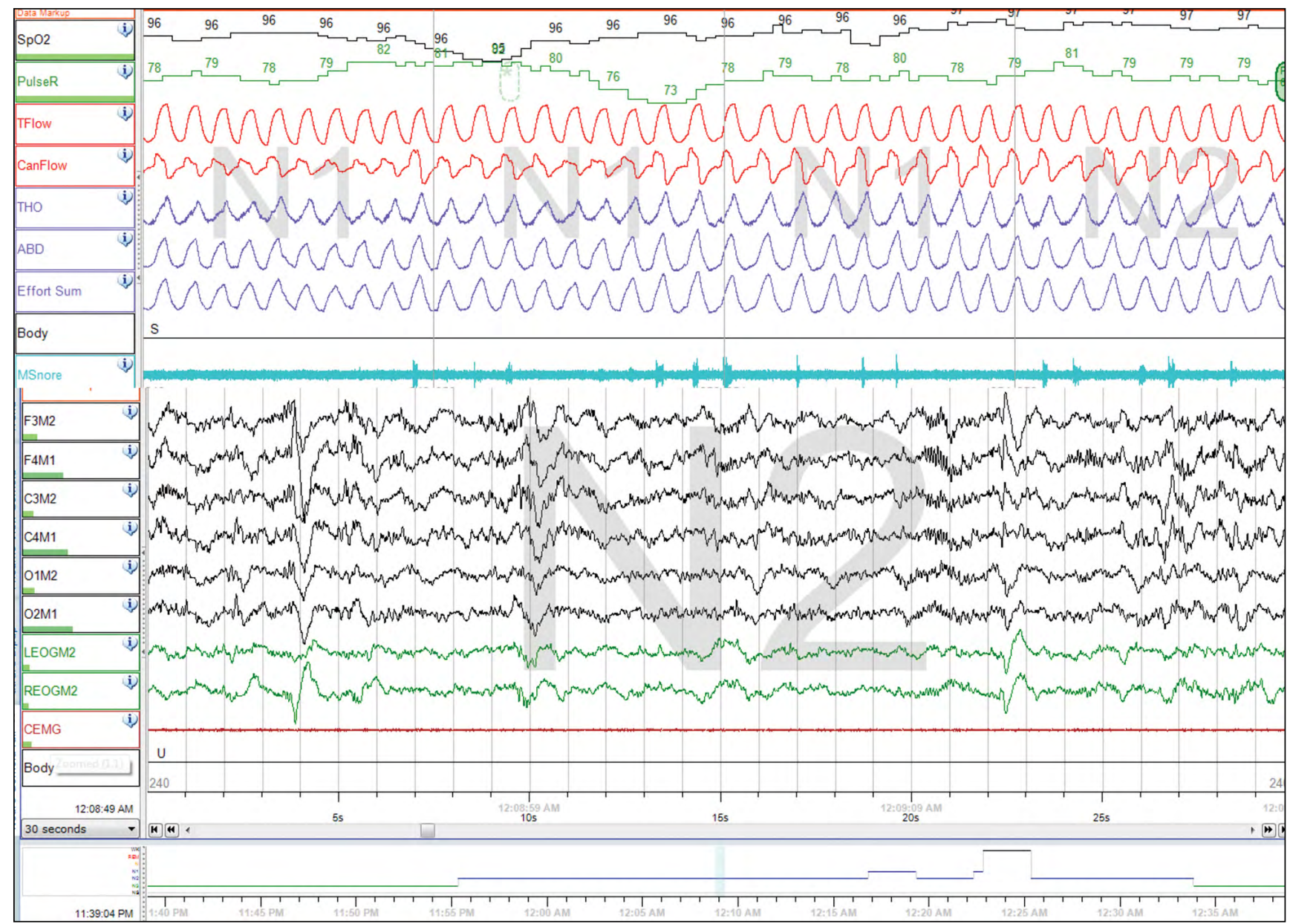

FIGURA 1. Traseu polisomnografic la copil - epoca arată stadiul N2 al somnului, fără manifestări respiratorii obstructive, saturaţia oxigenului în limite normale (colecţie personală)

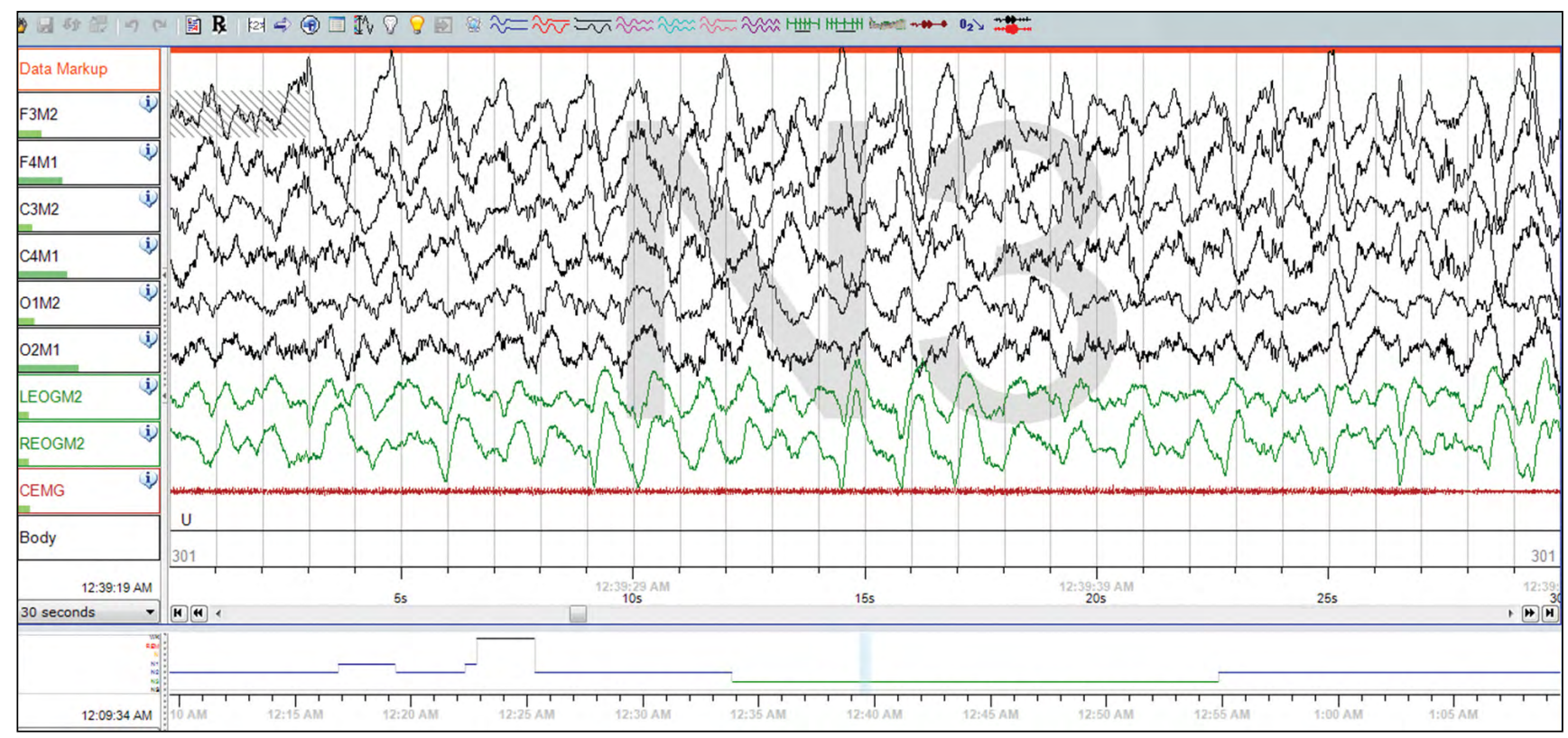

FIGURA 2. Traseu polisomnografic la copil: Stadiul N3 de somn - colecţie personală 


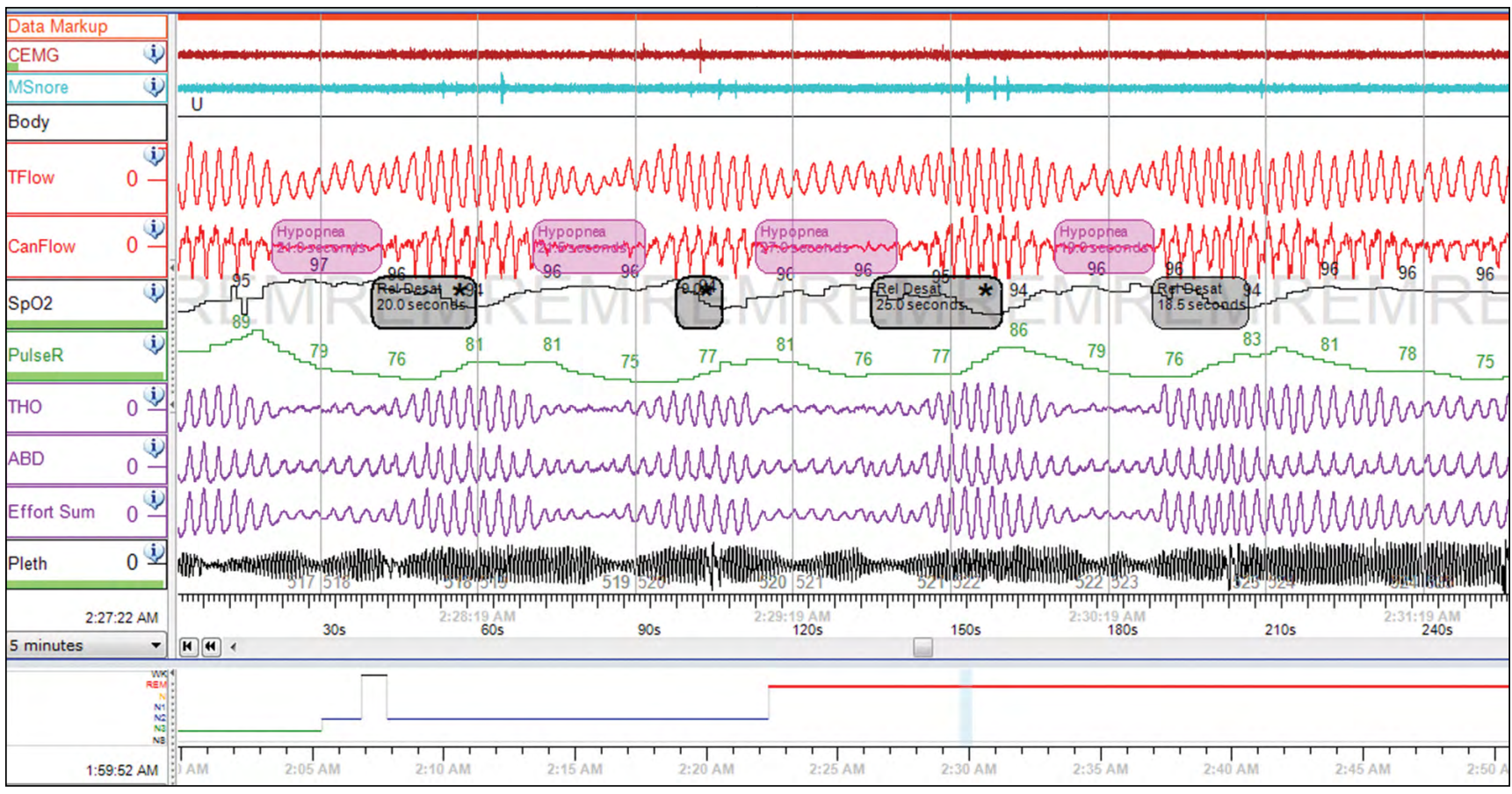

FIGURA 3. Traseu polisomnografic la copil: Hipopnei obstructive în stadiul REM - colecţie personală

TABEL 1. Evaluarea parametrilor pentru dezvoltarea SASO la copiii cu tulburări respiratorii obstructive în timpul somnului adaptat după Khaditis $A$ et al. (7)

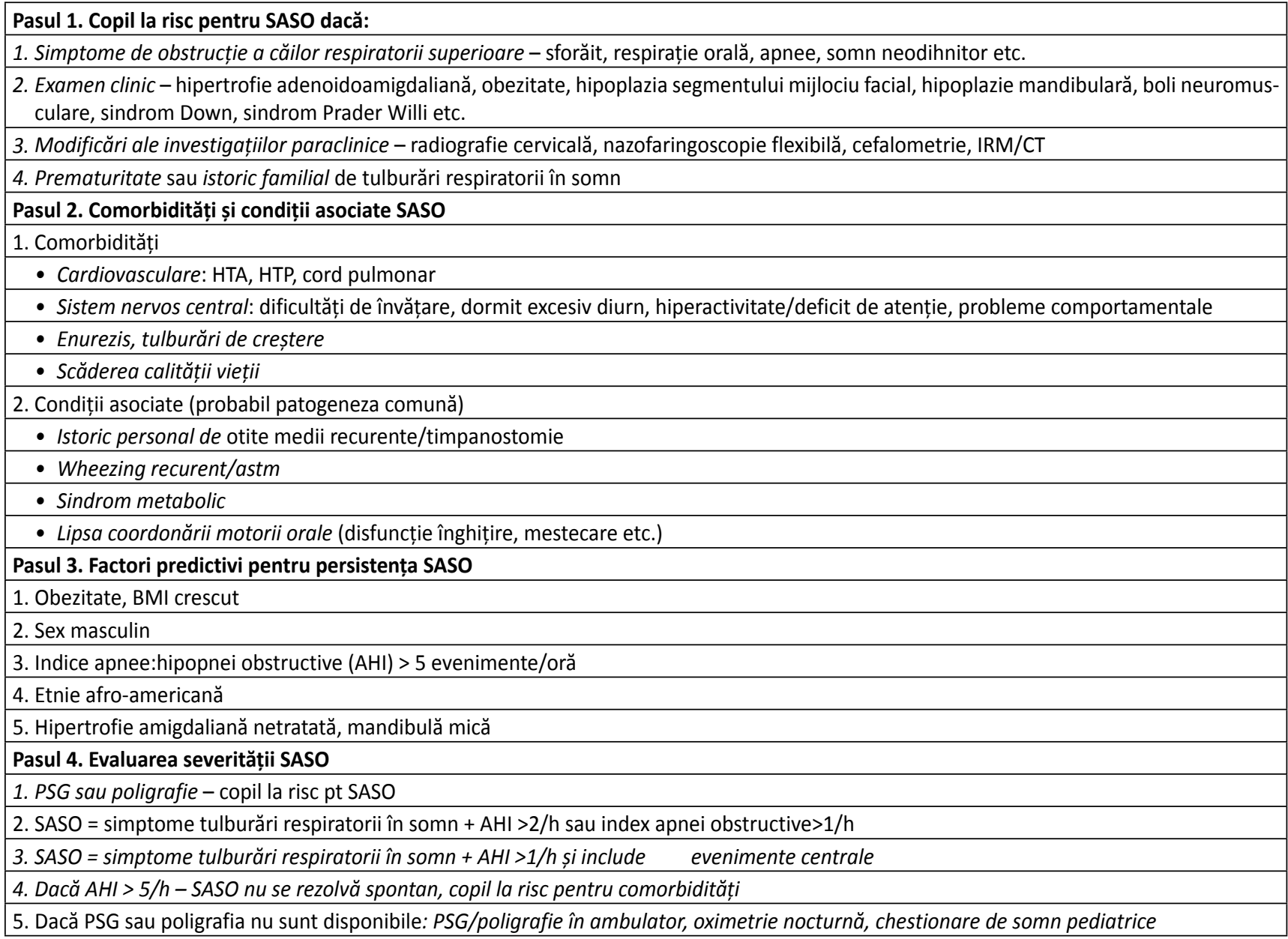


torii predictibili pentru o posibilă persistenţă a SASO. Scopul acestei evaluări este de a stabili severitatea SASO prin mecanisme obiective de investigare diagnostică.

Literatura de specialitate aduce numeroase informaţii despre impactul pe care comorbidităţile asociate tulburărilor obstructive respiratorii din timpul somnului îl au asupra diverselor sisteme şi organe. Acestea pot să devină factor declanşator, pot să susţină sau să accentueze patologia SASO în rândul populaţiei pediatrice.

Studiile din literatură arată că prevalenţa SASO în rândul populaţiei pediatrice cu obezitate variază între $13 \%$ şi $59 \%$ (8), iar creşterea procentuală este direct proporţională cu gradul obezităţii (9). Sindromul metabolic şi SASO sunt 2 entităţi frecvent asociate la pacienţii obezi, iar scăderea în greutate este o strategie de viaţă care ameliorează ambele patologii (7).

De asemenea, bolile neuromusculare asociază în evoluţie o formă de tulburări respiratorii, gradul de severitate al SASO fiind dependent de vârsta la debut şi de tipul afecţiunii neuromusculare, de gradul de afectare a muşchilor respiratori şi de complianţa pacienţilor la tratament. Studiul lui Mellies şi colab. (10) arată că, în cazul copiilor diagnosticaţi cu boli neuromusculare care asociază o scădere a capacităţii vitale inspiratorii $<60 \%$, aceste valori devin un factor de prognostic negativ asociat cu prezenţa SASO, iar o scădere $<40 \%$ poate prezice asocierea SASO cu hipoventilaţia nocturnă.

Tulburările respiratorii obstructive în timpul somnului pot să apară chiar în absenţa unei simptomatologii diurne sau nocturne conştientizate de către pacient sau de anturaj (8).

Chestionarul de somn pediatric este validat ca instrument pentru evaluarea tulburărilor respiratorii în timpul somnului (9). Acesta se aplică pacientului şi punctează semne şi simptome importante pentru dezvoltarea acestei patologii: prezenta sforăitului, a apneilor, somnolenţa diurnă, trezit cu dificultate dimineaţa, cefalee, tulburări de concentrare, tulburări de atenţie, dificultăţi în memorarea şi efectuarea diverselor sarcini, agitaţie, emisii involuntare de urină, modificarea ritmului de creştere etc. În funcţie de scorul obţinut, se ridică suspiciunea unei posibile tulburări de somn şi se suplimentează investigaţiile în funcţie de patologia pacientului (9).

Polisomnografia cardiorespiratorie este investigaţia considerată metoda standard pentru diagnosticarea SASO la orice vârstă.

Asociaţia Americană de Pediatrie şi Asociaţia Americană de Somnologie recomandă ca metodă obiectivă de evaluare a SASO polisomnografia nocturnă, efectuată în laboratorul de somn, sub suprave- ghere medicală (7). Cealaltă metodă de investigaţie acceptată este poligrafia cardiorespiratorie (7).

Polisomnografia efectuată în timpul somnului diurn, polisomnografia ambulatorie, oximetria nocturnă sau înregistrările video pot fi propuse ca metode alternative de evaluare a tulburărilor respiratorii în timpul somnului dacă polisomnografia standard nu este accesibilă (7).

Polisomnografia sau poligrafia se recomandă copiilor cu simptomatologie SASO şi anterior practicării adenotonsilectomiei mai ales în prezenţa comorbidităţilor: obezitate, boli neuromusculare sau alte boli genetice şi de metabolism, dismorfism cranio-facial (7).

Polisomnografia sau poligrafia se recomandă postadenotonsilectomie copiilor care menţin SASO persistent sau au prezentat o formă SASO moderat-severă anterior intervenţiei chirurgicale, cât şi copiilor care asociază comorbidităţile menţionate mai sus (7).

Polisomnografia sau poligrafia au indicaţie anterior şi postaplicare de dispozitive ortodontice sau după operaţia de expansiune maxilară, cât şi pentru stabilirea parametrilor necesari ventilaţiei noninvazive $\mathrm{cu}$ presiune pozitivă (7).

Regulile pentru interpretarea parametrilor somnului şi a celor cardiorespiratori înregistraţi polisomnografic sunt bine definite de către Asociaţia Americană de Somnologie (AASM) prin manuale updatate periodic.

Indicele de apnei:hipopnei reprezintă numărul de evenimente respiratorii înregistrat în timpul somnului (apnei/hipopnei mixte, obstructive sau de tip central) raportate la timpul total de ore de somn şi este exprimat în număr de evenimente per oră. Acest indice este unul dintre cei mai utilizaţi parametri ai polisomnografiei în interpretarea gradului de severitate a SASO (12).

Coroborând datele anamnestice cu examenul clinic şi cu rezultatul investigaţiilor efectuate individualizat fiecărui copil în parte, se stabileşte diagnosticul de SASO, gradul de severitate a tulburărilor respiratorii, precum şi răsunetul pe termen mediu şi lung al acestei patologii asupra organismului. În funcţie de rezultatul polisomnografiei şi de starea clinică a pacientului, se decide modul de abordare atât a patologiei respiratorii, cât şi a celei conexe.

Tabelul 2 menţionează principalele modificări ale parametrilor necesari pentru instituirea tratamentului, posibilele abordări terapeutice ale copilului cu tulburări respiratorii obstructive în somn şi stabileşte strategiile de follow-up atât în cazul unei evoluţii favorabile, cât şi în cazul persistenţei SASO.

Indicaţiile pentru iniţierea tratamentului în cazul prezenţei SASO la un copil sunt diferenţiate în funcţie de valorile IAH şi de patologia uneori complexă a co- 
TABEL 2. Managementul SASO la copiii cu tulburări respiratorii obstructive în timpul somnului - adaptat după Khaditis A et al. (7)

\begin{tabular}{|l|}
\hline Pasul 5. Indicații tratament SASO \\
\hline 1. AHI > 5/h, +/- comorbidități \\
2. AHI < $5 /$ h + comorbidități cardiovasculare/SNC, enurezis, tulburări de creștere, scăderea calității vieții, prezența factorilor de risc predictivi \\
3. Reevaluare anuală a sforăitului primar \\
4. Prioritare: prezența anomaliilor craniofaciale, a bolilor neuromusculare, acondroplazie, malformație Chiari, sindrom Down, MPZ, sindrom \\
Prader-Willi \\
\hline Pasul 6. Modalități de tratament \\
\hline 1. Igiena somnului \\
2. Scădere în greutate - supraponderal/obez \\
3. Medicație corticosteroidiană topic nazal sau oral \\
4. Adenotonsilectomie \\
5. Dispozitive ortodontice, expansiune maxilară \\
6. Ventilație noninvazivă nocturnă cu presiune continuă pozitivă \\
7. Chirurgie craniofacială \\
8. Traheostoma \\
\hline Pasul 7. Follow-up, recunoașterea și managementul SASO persistent \\
\hline 1. Monitorizare periodică la 6 săptămâni-12 luni prin evaluare simptomatică, PSG, calitatea vieții, comorbidități \\
2. PSG - de elecție pentru detectarea SASO rezidual. Dacă PSG nu e disponibilă: poligrafie, oximetrie, capnografie \\
3. PSG la 6 săptămâni după adenotonsilectomie dacă persistă SASO sau dacă copilul este la risc \\
4. PSG la 12 săptămâni după tratament corticosteroid oral sau intranazal \\
5. PSG la 12 luni după expansiune maxilară (mai repede dacă persistă simptomele) și la 6 luni după aplicarea dispozitivelor orale \\
6. PSG pentru titrare în vederea inițierii sau menținerii ventilației nocturne cu presiune continuă pozitivă \\
7. Reevaluarea căilor respiratorii superioare prin nazofaringoscopie, endoscopie, IRM \\
\hline
\end{tabular}

pilului. Astfel, chiar dacă rezultatul PSG arată un IAH de 1-5/oră, tratamentul se poate iniţia în condiţiile în care pacientul prezintă risc crescut de morbiditate prin factori cardiovasculari, dacă este modificată calitatea vieţii sau dacă asociază factori de risc cunoscuţi că pot agrava SASO (7).

Indicaţiile de tratament în cazul diagnosticării SASO la un copil cuprind măsuri de îmbunătăţire a calităţii somnului asociate cu terapie medicamentoasă, terapie intervenţională sau de aplicare a aparatelor de ventilaţie noninvazivă cu presiune continuă pozitivă.

Strategiile educaţionale pentru o bună igienă a somnului (AASM) (13) sunt următoarele:

- Respectarea unui ritual pentru somn (aceleaşi ore pentru adormit şi trezit);

- Camera de dormit departe de zgomote, întunecată, răcoroasă;

- Evitarea lichidelor în exces înainte de culcare;

- Evitarea factorilor stimulatori/excitanţi înainte de oră de somn (activităţi, cafeină, medicaţie stimulantă etc.)

- Respectarea orarului meselor

- Respectarea orelor de somn

- Poziţie de dormit (decubit lateral, poziţie înclinată a patului)

- Exerciţii vocale pentru stimularea musculaturii gâtului

Medicaţia administrată pentru ameliorarea simptomatologiei SASO poate cuprinde: soluţii saline nazale, decongestionante nazale, antihistaminice (în caz de rinită alergică), corticoterapie (intranazal/oral), terapia orală cu antileucotriene etc. (6).

Într-un studiu publicat în 2012, Goldbart AD şi colab. concluzionează că administrarea corticosteroizilor intranazal sau oral copiilor cu SASO moderat-sever pentru o perioadă de 6-12 săptămâni reduce severitatea SASO, IAH şi dimensiunea adenoizilor, cu efecte mai slabe însă asupra populaţiei pediatrice obeze (14).

Adenotonsilectomia este indicaţia chirurgicală de elecţie la copiii cu SASO care asociază hipertrofie adenoidoamigdaliană. Intervenţia chirurgicală îmbunătățeşte parametrii cardiovasculari, ameliorează simptomatologia neurocomportamentală şi calitatea vieţii (13).

Cele mai frecvente abordări terapeutice chirurgicale sunt următoarele:

1. adenotonsilectomie

2. tonsilotomie

3. traheostomie

4. plastie: uvulopalatofaringoplastie, uvulopalatoplastie

5. ablaţie prin radiofrecvenţa la nivelul palatului moale

6. implant la nivelul palatului moale etc.

Terapia prin ventilaţie nocturnă cu presiune continuă pozitivă se adresează copiilor cu SASO rezidual postadenotonsilectomie, SASO asociat cu obezitate, anomalii cranio-faciale sau boli neuromusculare şi în cazul eşecului celorlalte forme terapeutice. 
Terapia prin ventilaţie cu presiune pozitivă are ca efect îmbunătăţirea schimburilor gazoase, ameliorarea simptomatologiei (starea de somnolenţă, tulburările respiratorii din timpul somnului, tulburările de comportament sau de concentrare etc.) şi, astfel, determina îmbunătăţirea calităţii vieţii pacientului. Aderenţa la terapia prin ventilaţie cu presiune pozitivă este variată şi dependentă de ameliorarea simptomelor, de disponibilitatea familială, de educaţie, de percepţia şi înţelegerea beneficiilor tratamentului (2).

În cazul copiilor cu forme uşoare de SASO şi al pacienţilor care prezintă complianţă scăzută pentru aparatul de ventilaţie noninvazivă cu presiune continuă pozitivă, se poate apela la dispozitivele antisforăit pentru a ameliora simptomele şi pentru a îmbunătăţi calitatea vieţii copiilor.

Dispozitivele antisforăit pot fi: dispozitive nazale (benzi nazale, dilatatoare nazale), dispozitive orale (benzi pt bărbie, dispozitive bucale), dispozitive de repoziţionare mandibulară (7).

Lipsa aplicării tratamentului personalizat în funcţie de antecedentele copilului şi de rezultatul investigaţiilor conduce în timp la instalarea complicaţiilor derivate din accentuarea bolii de bază şi, implicit, din agravarea tulburărilor respiratorii în timpul somnului.

Un bun răspuns terapeutic presupune comunicarea permanentă medic-pacient, măsuri corecte de trata-

\section{BIBLIOGRAFIE}

1. Simonds AK, Backer W et al. ERS Handbook. Respiratory Sleep Medicine. Page Bros. UK. 2012; 205-210.

2. Spriggs WH. Essentials of polysomnography. A training guide and reference for sleep technicians. Jones \& Bartlett Learning, 2014.

3. Liukkonen K. Snoring and sleep apnea in children. University of Helsinki, Faculty of Medicine, Institute of Clinical Medicine, 2011.

4. Lumeng JC, Chervin RD. Epidemiology of Pediatric Obstructive Sleep apnea. Proc Am Thorac Soc. 2008;5(2):242-252.

5. Plesca DA, Chindris S, Avramuta A. Obesity and obstructive sleep apnea in children. The Publishing House of the Romanian Academy. 2015;1:3-5

6. Cataletto ME, Serebrisky D et al. Childhood Sleep Apnea - Available at https://emedicine.medscape.com/article/1004104-overview.

7. Kaditis AG, Alvarez ML et al. Obstructive sleep disordered breathing in 2 to 18 -year-old children: Diagnosis and management. Eur Respir J. 2016;47:69-94.

8. New Zealand Guidelines for the Assessment of Sleep-Disordered Breathing in Childhood. Paediatric Society of New Zealand, 2015. ment, înţelegerea şi aplicarea acestora la domiciliu, reevaluări periodice bine stabilite şi recunoaşterea precoce a unor posibile complicaţii ale bolii sau ale tratamentului prescris.

\section{CONCLUZII}

Tulburările respiratorii obstructive apărute în timpul somnului la copil rămân o continuă provocare pentru experţii în domeniu. Echipe multidisciplinare se unesc să înţeleagă mecanismele care stau la baza acestei patologii pentru a putea găsi noi resurse de tratament şi noi modalităţi de prevenţie.

Rolul medicului este de a dobândi cât mai multe cunoştinţe în domeniu, pentru a putea asigura copilului o evaluare clinico-biologică şi o strategie terapeutică cât mai exacte şi axate pe caracteristicile individuale pe care această patologie le determină, în corelaţie cu factorii genetici, patofiziologici şi de mediu implicaţi.

Rezultă, astfel, o unitate individuală, complexă, variată, definitorie pentru fiecare individ în parte, o provocare pentru generaţiile medicale actuale şi viitoare care încearcă să înţeleagă, să găsească răspunsuri şi soluţii pentru o cât mai bună păstrare a acestui tot unitar.

Conflict of interest: none declared Financial support: none declared

9. Oros M. Tulburarile de somn la sugar, copil mic si adolescent. Medichub, 2017.

10. Mellies U, Ragette R, Schwake C et al. Daytime predictors of sleep disordered breathing in children and adolescents with neuromuscular disorders. Neuromuscul Disord. 2003;13:123-128.

11. Suresh $S$, Wales $P$, Dakin $C$ et al. Sleep-related breathing disorder in Duchenne muscular dystrophy: Disease spectrum in the paediatric population. J Paediatr Child Health. 2005;41:500-503.

12. Spriggs WH. Essentials of Polysomnography. Jones \& Bartlett Learning. 2014;100-328.

13. Iber $C$ et al. The AASM manual for the scoring of sleep and associated events : rules, terminology and technical specifications. American Academy of Sleep Medicine. 2007;1-80.

14. Goldbart AD, Greenberg-Dotan S, Tal A. Montelukast for children with obstructive sleep apnea: A double-blind, placebo-controlled study. Pediatrics 2012;130:575-80. 